\title{
Dendroaspis natriuretic peptide is degraded by a metalloproteinase in the rat kidney
}

\author{
SOO MI KIM ${ }^{*}$, SUN YOUNG KIM* ${ }^{*}$, SUHN HEE KIM ${ }^{* *}$ and SUNG ZOO KIM ${ }^{* *}$ \\ Department of Physiology, Institute for Medical Sciences, Chonbuk National University Medical School, \\ Jeonju, Jeonbuk 561-180, Republic of Korea
}

Received April 30, 2013; Accepted December 3, 2013

DOI: $10.3892 / \mathrm{mmr} .2013 .1871$

\begin{abstract}
Our previous study demonstrated that the concentration of dendroaspis natriuretic peptide (DNP) was markedly higher than that of atrial NP (ANP) in rabbit plasma, indicating that DNP has a different metabolic rate from other NPs. Therefore, the metabolic characteristics of DNP in mammals require further analysis. The stabilities of NPs were determined by incubating ${ }^{125}$ I-labeled ANP, brain NP (BNP), C-type NP (CNP) and DNP at $37^{\circ} \mathrm{C}$ for 1,2 and $4 \mathrm{~h}$, and analyzing their profiles by reversed-phase high-performance liquid chromatography. ${ }^{125}$ I-labeled ANP, BNP and CNP were quickly degraded in rat plasma, while ${ }^{125} \mathrm{I}$-labeled DNP was stable for $4 \mathrm{~h}$. The relative stability of the peptides following incubation in rat plasma followed the rank order of: DNP $\gg>A N P \geq B N P>C N P$. Organs were also examined for the degradation of DNP, including the spleen, kidney, liver, heart and lung. The physiological target organ for the degradation of DNP was observed to be the kidney. Furthermore, degradation of DNP in the kidney was attenuated by phenanthroline, a metalloproteinase inhibitor. Therefore, these results indicate that DNP has a longer stability in plasma and that it may have strong therapeutic applications in cardiac disease.
\end{abstract}

\section{Introduction}

Natriuretic peptides (NPs) are a family of polypeptide hormones that regulate blood pressure and fluid balance by directly affecting the kidney and the systemic vasculature. Since dendroaspis NP (DNP) has been isolated recently from the venom of snakes, the NP family now contains four

Correspondence to: Dr Suhn Hee Kim or Dr Sung Zoo Kim, Department of Physiology, Chonbuk National University, Medical School, 2-20 Keum-Am-Dong-San, Jeonju, Jeonbuk 561-180, Republic of Korea

E-mail: shkim@jbnu.ac.kr

E-mail: szkim@jbnu.ac.kr

*Contributed equally

${ }^{* *}$ Contributed equally

Key words: dendroaspis natriuretic peptide, stability, kidney, metalloproteinase members: Atrial NP (ANP), brain NP (BNP), C-type NP (CNP) and DNP (1-5). While ANP is secreted from atrial myocytes in response to an increased intravascular volume, BNP is synthesized mainly in the ventricular myocardium and is released into the blood (6). The effects of ANP are largely on the blood vessels and kidneys, where it leads to natriuresis, diuresis and a decrease in intravascular volume and blood pressure (7). The actions of BNP are similar to those of ANP, and these two peptides are hypothesized to be circulating hormones. By contrast, CNP is likely to be an autocrine or paracrine mediator, as it is only detected at extremely low levels in the plasma (8). In fact, CNP has lower hypotensive and natriuretic properties compared with ANP and BNP (9). However, contrary to our understanding of ANP, BNP and $\mathrm{CNP}$, the role of DNP in mammals remains unclear.

Our recent study demonstrated that the concentration of DNP was relatively high in rabbit plasma, while the tissue contents of DNP in various organs, including the liver, spleen, intestine, atrium, ventricle, septum, kidney, cerebrum and cerebellum, were quite low (10). The major sites for DNP synthesis and secretion have not been identified, although the concentration of DNP in the plasma was markedly higher compared with that of ANP in the rabbit. Notably, the high plasma concentrations of DNP were identified to be correlated with the biological half-life of DNP in the circulation of the rabbit (10). Since the stability of DNP in plasma is a significant factor with regard to its half-life and renal functions, the current experiments were designed to confirm the stability of DNP versus ANP, BNP and CNP in rat plasma, and to determine a physiological target site for the degradation of DNP. In addition, the present study was undertaken to investigate the metabolism of DNP and to determine whether degradation of DNP stability may be mediated by specific proteinases.

\section{Materials and methods}

Plasma and tissue preparation. A total of 30 male Sprague Dawley rats (Daehan Biolink Co. Ltd., Chungbuk, South Korea) were used for the study. All the experiments conformed to the guidelines of the National Institutes of Health (Bethesda, MA, USA) and were performed with the approval of the Institutional Animal Care and Use Committee of Chonbuk National University (Jeonju, Korea). The rats were euthanized under ketamine/xylazine (90 and $10 \mathrm{mg} / \mathrm{kg}$, 
respectively) anesthesia. For sampling of the plasma, the arterial blood was collected into pre-chilled tubes containing ethylenediaminetetraacetic acid (EDTA), $1 \mathrm{mg} / \mathrm{ml}$ whole blood, phenylmethylsulfonyl fluoride $(0.4 \%)$ and soybean trypsin inhibitor $\left(N_{\alpha}\right.$-benzoyl-L-arginine ethyl ester, $\left.50 \mathrm{U} / \mathrm{ml}\right)$. The plasma samples were obtained following centrifugation at $10,000 \mathrm{x} \mathrm{g}$ for $15 \mathrm{~min}$ at $4^{\circ} \mathrm{C}$. The finely-diced pooled kidney, liver, spleen and lung tissues from five rats were homogenized at $4^{\circ} \mathrm{C}$ in $30 \mathrm{mM}$ phosphate buffer (pH 7.4) and by three 30 -sec bursts at 1,000 rpm (Polytron homogenizer, Fisher Scientific, Waltham, MA, USA). The homogenate was centrifuged at $1,000 \mathrm{x}$ g for $10 \mathrm{~min}$ at $4^{\circ} \mathrm{C}$ and the supernatant was collected.

Iodination of ANP, BNP, CNP and DNP. ${ }^{125} \mathrm{I}-\mathrm{ANP}$, -BNP, -CNP and -DNP were prepared as described previously (11). Synthetic ANP, BNP, CNP and DNP $(5 \mu \mathrm{g} / 5 \mu \mathrm{l}$ $0.1 \mathrm{M}$ acetic acid; Peninsula Laboratories, Belmont, CA, USA) were introduced into vials containing $25 \mu 10.5 \mathrm{M}$ phosphate-buffered saline ( $\mathrm{pH} 7.4$ ), followed by addition of $1 \mathrm{mCi}{ }^{125} \mathrm{I}-\mathrm{Na}$ (Amersham International, Buckinghamshire, UK). Chloramine-T $(10 \mu \mathrm{g} / 10 \mu \mathrm{l})$ was added to the reaction vials, which were mixed gently. After $30 \mathrm{sec}$, bovine serum albumin (BSA; $60 \mathrm{mg} / 200 \mu \mathrm{l}$ ) was added. The reaction mixture was immediately applied to a Sephadex G-25 column (1.0 x 24 cm; GE Healthcare Life Science, Pittsburgh, PA, USA) and eluted with $0.1 \mathrm{~N}$-acetic acid containing $0.3 \% \mathrm{BSA}$, $0.3 \%$ lysozyme, $0.1 \%$ glycine and $200 \mathrm{KIU} / \mathrm{ml}$ of aprotinin. Iodinated ANP, BNP, CNP and DNP were divided and stored at $-70^{\circ} \mathrm{C}$ until further use. The iodinated ANP, BNP, CNP and DNP were purified by high-performance liquid chromatography (HPLC) on a reversed-phase Bondapak Column (Waters Associates, Milford, MA, USA) with a linear gradient ( 0 to $60 \%$ acetonitrile) elution immediately prior to use $(12,13)$.

Stability of ${ }^{125}$ I-labeled ANP, BNP, CNP and DNP. The stability of the NPs was determined. In order to compare the stability of ANP to DNP, ${ }^{125}$ I-labeled ANP, BNP, CNP and DNP were incubated in rat plasma at $37^{\circ} \mathrm{C}$ for 1,2 and $4 \mathrm{~h}$. A reversed-phase HPLC C18 Bondapak column $(4.5 \times 2,500 \mathrm{~mm}$; Waters Associates) was used for analyzing the ${ }^{125}$ I-labeled ANP and DNP. In total, $\sim 100 \mu 1$ incubated ${ }^{125}$ I-labeled peptide solution in plasma from each time-point $(0,1,2$ and $4 \mathrm{~h}$ after incubation) was loaded and then eluted on a linear gradient of $0-60 \%$ acetonitrile with $0.1 \%$ trifluoroacetic acid (40 min; flow rate, $1 \mathrm{ml} / \mathrm{min}$ ). Degradation of the ${ }^{125} \mathrm{I}$-labeled ANP, BNP, CNP and DNP in the plasma was estimated by counting the radioactivity of the HPLC fractions.

Proteinase inhibitors. To investigate the main organ sites for DNP degradation, ${ }^{125}$ I-labeled DNP was incubated at $37^{\circ} \mathrm{C}$ for $4 \mathrm{~h}$ in the rat kidney, spleen, liver and lung. The quantity of protein in the tissue extracts from the spleen, lung and liver was measured and used in equal quantities $(5 \mu \mathrm{g} / \mu \mathrm{l})$. In addition, to further address the stability of DNP and determine which proteinase degrades DNP, the following proteinase inhibitors were used: The metalloproteinase, phenanthroline; the serine-cysteine proteinase, leupeptin; the serine-proteinase, aprotinin; the acid-proteinase, pepstatin; and the amino-proteinase, bacitracin.
Statistical analysis. The data are presented as the mean \pm standard error of the mean. Statistical comparisons were performed using an unpaired Student's t-test and one-way analysis of variance, followed by the multiple comparison Bonferroni t-test. $\mathrm{P}<0.05$ was considered to indicate a statistically significant difference.

\section{Results}

HPLC profiles of ${ }^{125}$ I-labeled ANP, BNP, CNP and DNP during incubation in rat plasma. Radioactive values of ${ }^{125}$ I-labeled ANP, BNP, CNP and DNP were determined. ${ }^{125}$ I-labeled ANP, BNP, CNP and DNP each had one peak with a high level of radioactivity at $0 \mathrm{~h}$ of incubation of the rat plasma (Fig. 1, Aa, Ba, Ca and Da). Following a 1-h incubation in rat plasma, two peaks were observed with ${ }^{125} \mathrm{I}$-labeled ANP, BNP, CNP and DNP (Figs. 1 and 2; peak 1 is a biologically active form and peak 2 is a degraded form of the peptide). ${ }^{125}$ I-labeled ANP, BNP and CNP demonstrated a significantly increased degradation peak at 2 and $4 \mathrm{~h}$ following incubation in the rat plasma (Figs. 1 and 2), while ${ }^{125}$ I-labeled DNP did not reveal any differences until $4 \mathrm{~h}$ of incubation in the rat plasma (Figs. 1 and 2). The relative stability of the peptides in the rat plasma was DNP $\gg>A N P \geq B N P \gg C N P$ (Table I and Fig. 2; $\mathrm{P}<0.05)$. These results indicate that DNP has the most stable structure amongst the various NPs in rat plasma.

Stability of ${ }^{125}$ I-labeled DNP in tissue extracts from kidney, liver, lung, heart and spleen. Since DNP was observed to be the most stable NP in plasma and may not be degraded rapidly by possible endogenous plasma proteinases, the present study sought to determine whether there is a physiological target site for the degradation of DNP in various organs. The lung, liver, spleen, kidney and heart were selected as target organs, as these organs play major roles in the metabolism of hormones. Therefore, the stability of DNP was determined by incubating ${ }^{125}$ I-labeled DNP in tissue extracts from the lung, liver, spleen, renal medulla, renal cortex, atrium and ventricle at $37^{\circ} \mathrm{C}$ for $1 \mathrm{~h}$ (Fig. 3). Following incubation, the molecular profiles of ${ }^{125}$ I-labeled DNP were analyzed. ${ }^{125}$ I-labeled DNP was significantly degraded in the tissue extracts from the renal cortex and medulla of the rats (Fig. 3E and F), indicating that the most favorable organ for the degradation of DNP may be the kidney.

Degradation rate of ${ }^{125}$ I-labeled DNP during incubation in tissue extracts from the kidney. ${ }^{125} \mathrm{I}$-labeled DNP was incubated in tissue extracts from the renal cortex at $37^{\circ} \mathrm{C}$ for 1,2 and $4 \mathrm{~h}$ (Fig. 4A). ${ }^{125}$ I-labeled DNP was significantly degraded in a time-dependent manner, as observed by the shifting from peak 1 towards peak 2 (Fig. 4B and C).

Effects of proteinase inhibitors on ${ }^{125}$ I-DNP stability. The mechanism by which DNP, mediated by other proteinases, is degraded in the renal cortex was investigated. Several types of proteinase inhibitors were used. As shown in Fig. 5, DNP was resistant to degradation by phenanthroline, a metalloproteinase inhibitor, regardless of time. However, leupeptin, a serine-cysteine proteinase inhibitor, significantly accelerated the degradation of ${ }^{125}$ I-labeled DNP following incubation for $4 \mathrm{~h}$. Aprotinin, a serine-proteinase inhibitor, also significantly 
Table I. Summary of bioactive degradation of ${ }^{125}$ I-labeled natriuretic peptides in plasma with a time-dependent manner. ${ }^{\mathrm{a}}$

\begin{tabular}{lcrrr}
\hline Peak & $0 \mathrm{~h}$ & \multicolumn{1}{c}{$1 \mathrm{~h}$} & \multicolumn{1}{c}{$\mathrm{h}$} \\
\hline ANP peak 1 & $53.2 \pm 4.6$ & $24.02 \pm 2.31^{\mathrm{b}}$ & $10.36 \pm 1.71^{\mathrm{b}}$ & $5.09 \pm 0.95^{\mathrm{b}}$ \\
ANP peak 2 & $2.63 \pm 0.2$ & $12.6 \pm 2.48^{\mathrm{c}}$ & $31.09 \pm 1.86^{\mathrm{d}}$ & $36.66 \pm 2.49^{\mathrm{d}}$ \\
BNP peak 1 & $73.47 \pm 2.43$ & $15.13 \pm 2.10^{\mathrm{b}}$ & $12.37 \pm 3.32^{\mathrm{b}}$ & $8.65 \pm 2.82^{\mathrm{b}}$ \\
BNP peak 2 & $0.25 \pm 0.15$ & $25.67 \pm 5.03^{\mathrm{d}}$ & $28.15 \pm 5.22^{\mathrm{d}}$ & $34.50 \pm 8.25^{\mathrm{d}}$ \\
CNP peak 1 & $29.14 \pm 6.51$ & $3.22 \pm 0.27^{\mathrm{b}}$ & $1.92 \pm 0.19^{\mathrm{b}}$ & $1.34 \pm 0.12^{\mathrm{b}}$ \\
CNP peak 2 & $4.7 \pm 0.9$ & $63.76 \pm 2.79^{\mathrm{d}}$ & $60.12 \pm 1.61^{\mathrm{d}}$ & $64.29 \pm 1.36^{\mathrm{d}}$ \\
DNP peak 1 & $45.15 \pm 2.17$ & $47.03 \pm 6.60$ & $43.03 \pm 9.55$ & $49.95 \pm 1.82$ \\
DNP peak 2 & $2.03 \pm 0.97$ & $0.21 \pm 0.16$ & $0.86 \pm 0.14$ & $0.66 \pm 0.19$
\end{tabular}

${ }^{a}$ Peak 1 is a biologically active form and peak 2 is a degraded form of the peptide. The values are expressed as the mean \pm standard error of the mean ${ }^{\mathrm{b}} \mathrm{P}<0.001$ vs. $0 \mathrm{~h}$ of peak $1 .{ }^{\mathrm{c}} \mathrm{P}<0.05$ and ${ }^{\mathrm{d}} \mathrm{P}<0.001$ vs. 0 h of peak 2 . ANP, atrial natriuretic peptide; BNP, brain natriuretic peptide; CNP, C-type natriuretic peptide; DNP, dendroaspis natriuretic peptide.
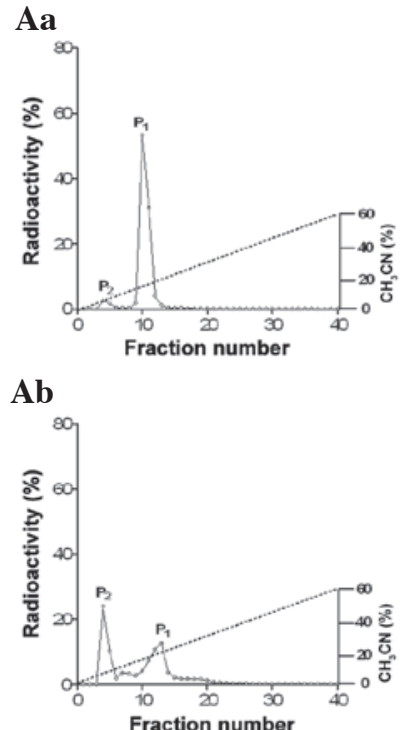

Ac
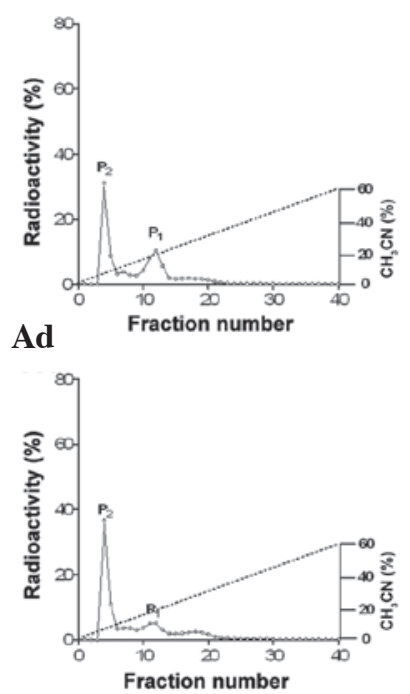

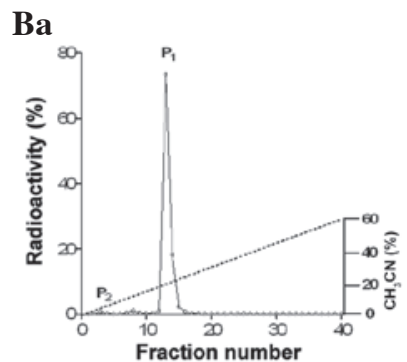

Bb

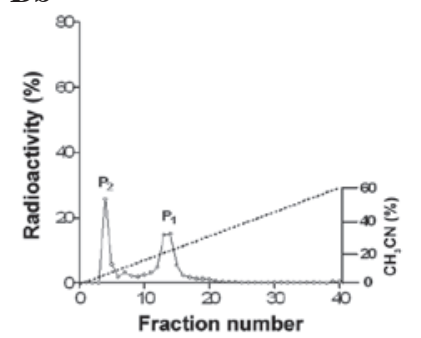

Bc

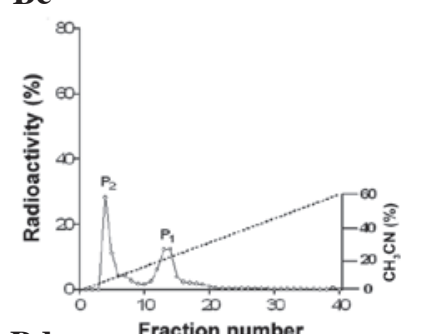

Bd

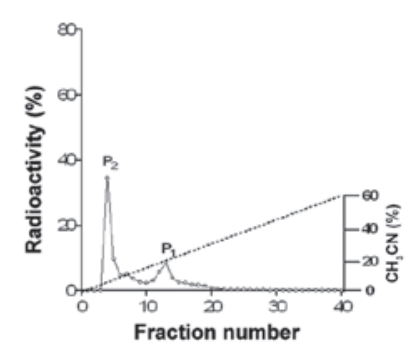

Ca

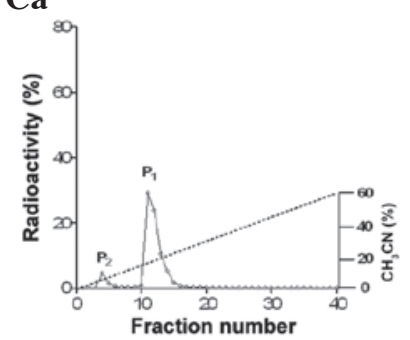

$\mathbf{C b}$

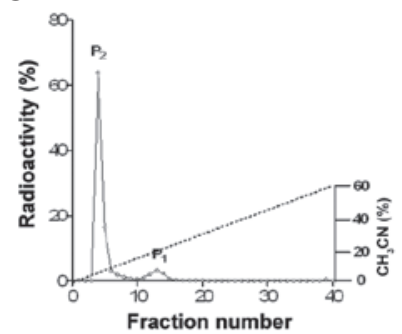

Cc

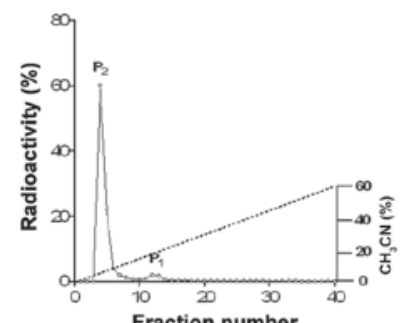

Cd

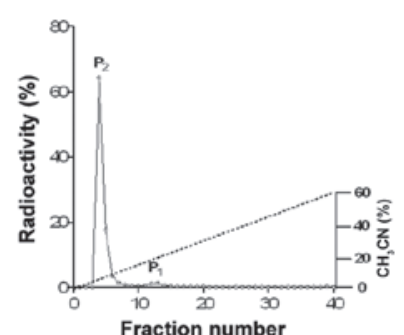

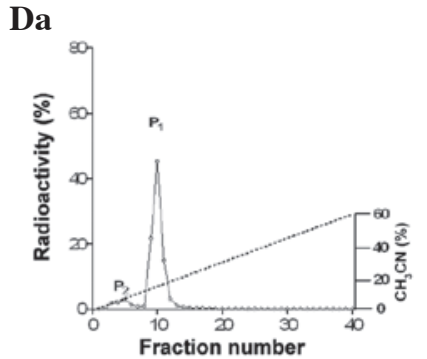

Db

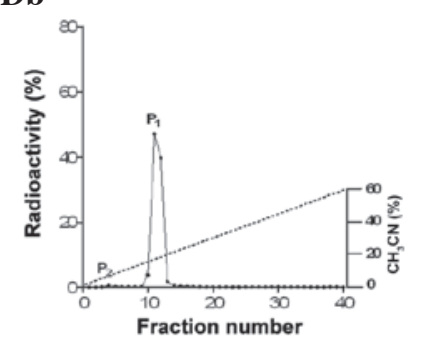

Dc

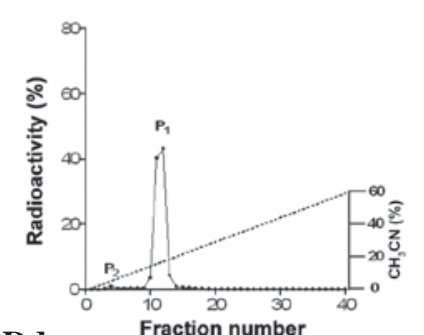

Dd

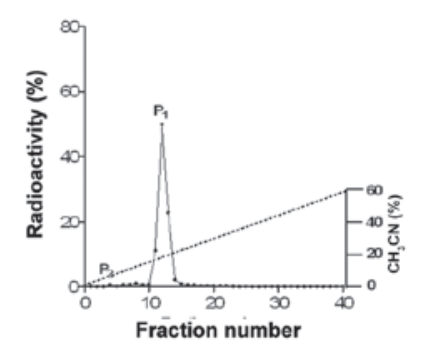

Figure 1. Comparison of the reversed-phase HPLC profiles of (Aa) ${ }^{125} \mathrm{I}-\mathrm{ANP},(\mathrm{Ba}){ }^{125} \mathrm{I}-\mathrm{BNP}$, (Ca) ${ }^{125} \mathrm{I}-\mathrm{CNP}$ and (Da) ${ }^{125} \mathrm{I}$-DNP during incubation in rat plasma at $37^{\circ} \mathrm{C}$ for $1 \mathrm{~h}(\mathrm{Ab}, \mathrm{Bb}, \mathrm{Cb}$ and $\mathrm{Db}), 2 \mathrm{~h}(\mathrm{Ac}, \mathrm{Bc}, \mathrm{Cc}$ and $\mathrm{Dc}$ ) and $4 \mathrm{~h}(\mathrm{Ad}, \mathrm{Bd}, \mathrm{Cd}$, and $\mathrm{Dd}$ ). Peak 1 (P1) is a biologically active form and peak $2(\mathrm{P} 2)$ is a degraded form of the peptide. All the experiments were performed more than five times. In total, $\sim 100 \mu 1^{125}$ I-labeled peptide solution incubated in plasma at each time point $(0,1,2$ and $4 \mathrm{~h}$ after incubation) was loaded and then eluted on a linear gradient of $0-60 \%$ acetonitrile with $0.1 \%$ trifluoroacetic acid (40 min; flow rate, $1 \mathrm{ml} / \mathrm{min})$ using a reversed-phase HPLC C18 Bondapak column $(4.5 \times 2,500 \mathrm{~mm})$. The degradation of ${ }^{125}$ I-labeled ANP, BNP, CNP and DNP in the plasma was estimated by counting the radioactivity of the HPLC fractions and expressed with a percentage ratio (\%). ANP, atrial natriuretic peptide; BNP, brain natriuretic peptide; CNP, C-type natriuretic peptide; DNP, dendroaspis natriuretic peptide; HPLC, high-performance liquid chromatography. 
A
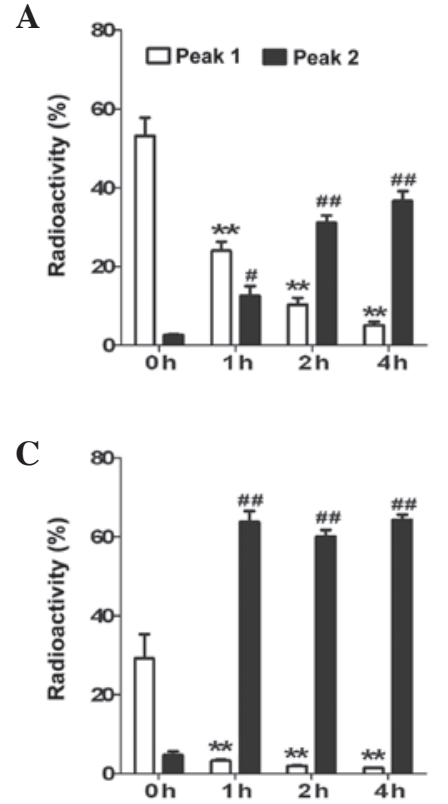
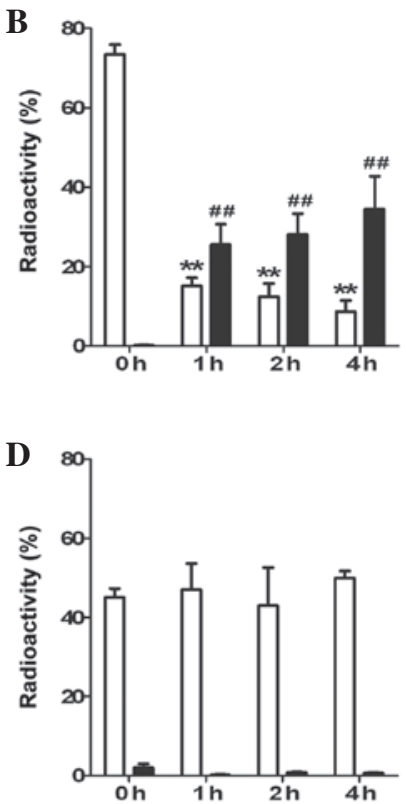

Figure 2. Stability of ${ }^{125}$ I-labeled natriuretic peptides with a time-dependent manner (A) ANP; (B) BNP; (C) CNP; and (D) DNP. The values are expressed as the mean \pm standard errors. ${ }^{* *} \mathrm{P}<0.001$ vs. $0 \mathrm{~h}$ of peak $1 .{ }^{\# \#} \mathrm{P}<0.001$ vs. $0 \mathrm{~h}$ of peak 2 . ANP, atrial natriuretic peptide; BNP, brain natriuretic peptide; CNP, C-type natriuretic peptide; DNP, dendroaspis natriuretic peptide.
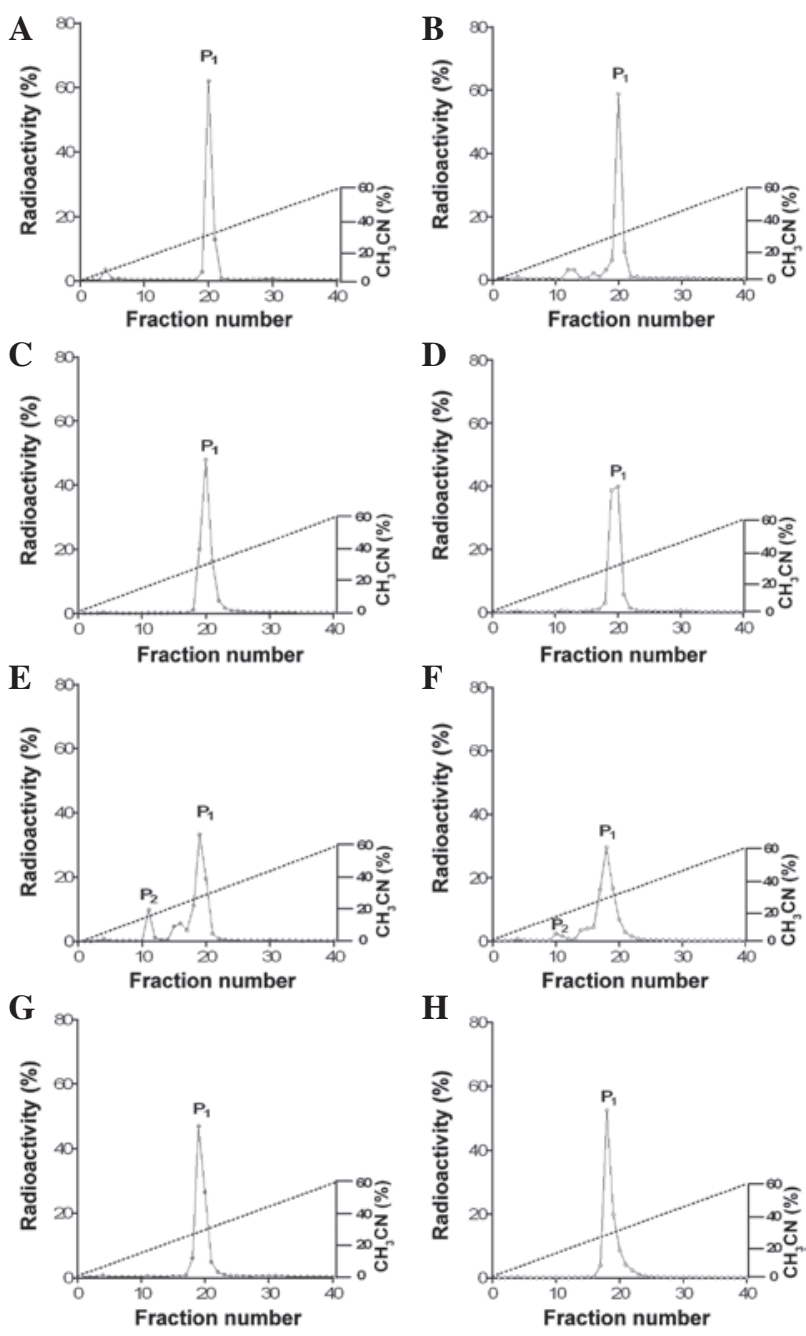

Figure 3. Reversed-phase HPLC profiles of ${ }^{125} \mathrm{I}-\mathrm{DNP}$ during incubation in various tissue extracts from rat at $37^{\circ} \mathrm{C}$ for $1 \mathrm{~h}$. (A) Without specimen (control); (B) lung; (C) liver; (D) spleen; (E) renal medulla; (F) renal cortex; (G) cardiac atrium and (H) cardiac ventricle. The degradation of ${ }^{125} \mathrm{I}-\mathrm{labeled} \mathrm{DNP}$ in tissue extracts was estimated by counting the radioactivity of the HPLC fractions and expressed with a percentage ratio (\%). HPLC, high-performance liquid chromatography; DNP, dendroaspis natriuretic peptide. 
A
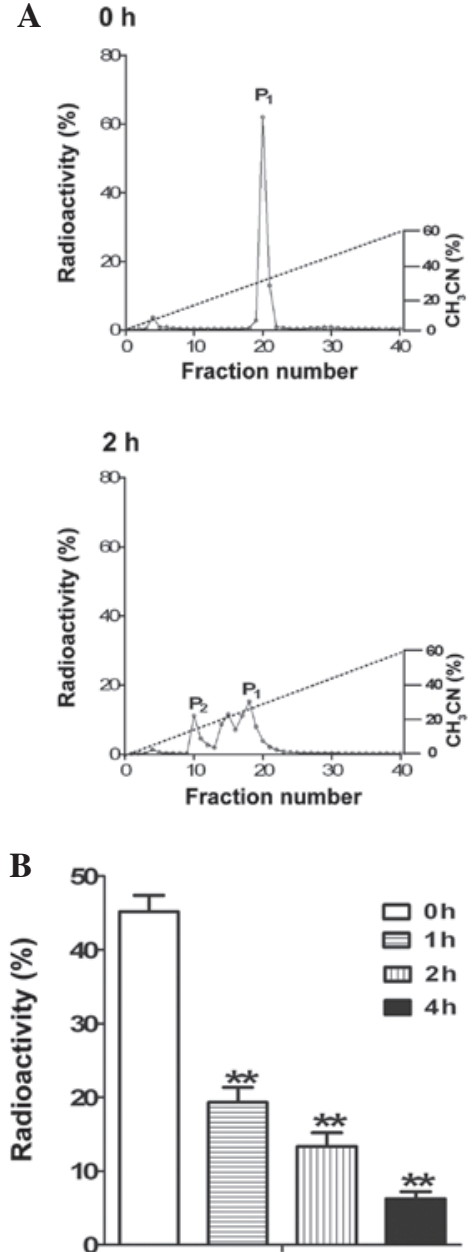

Peak 1
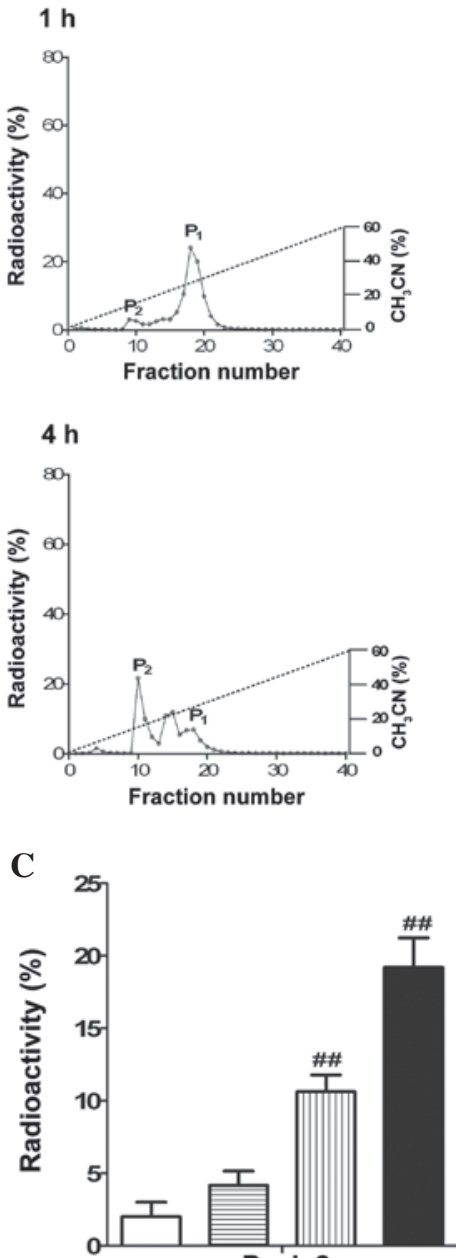

Peak 2

Figure 4. Reversed-phase HPLC profiles of ${ }^{125}$ I-DNP during incubation in rat kidney cortex at (A) $37^{\circ} \mathrm{C}$ for $0,1,2$ and $4 \mathrm{~h}$. The percentage of ${ }^{125}$ I-DNP stabilities in the rat kidney cortex (B) peak 1 and (C) peak 2 with a time-dependent manner. (B and C) The degradation of ${ }^{125}$ I-labeled DNP in tissue extracts from the kidney was estimated by counting the radioactivity of the HPLC fractions and expressed with a percentage ratio (\%). The values are expressed as the mean \pm standard error. ${ }^{* *} \mathrm{P}<0.001$ vs. $0 \mathrm{~h}$ of peak $1 .{ }^{\# \#} \mathrm{P}<0.001 \mathrm{vs} .0 \mathrm{~h}$ of peak 2 . HPLC, high-pressure liquid chromatography; DNP, dendroaspis natriuretic peptide.
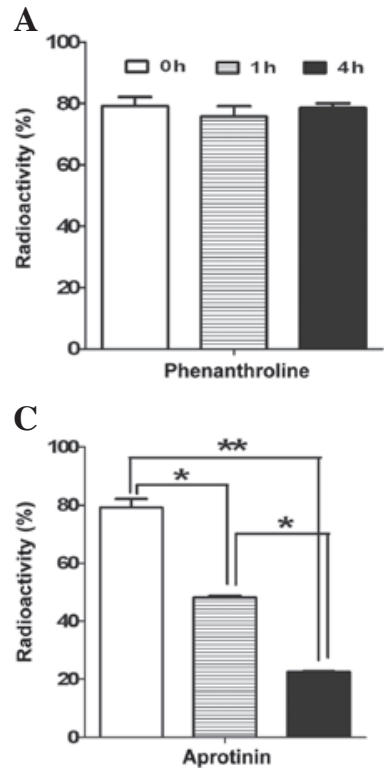

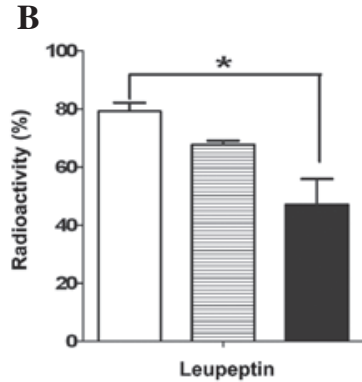

D

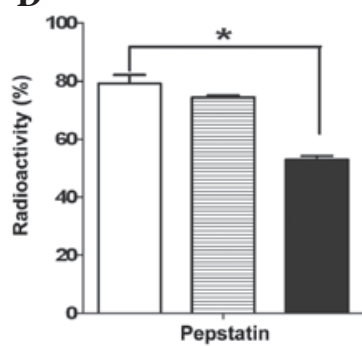

Figure 5. Effects of the proteinase inhibitors on ${ }^{125} \mathrm{I}$-DNP stability in the rat renal cortex at $37^{\circ} \mathrm{C}$ during a time-dependent incubation $(0,1$ and $4 \mathrm{~h})$. The degradation was estimated by counting the radioactivity of the HPLC fractions and expressed with a percentage ratio (\%). The values are expressed as the mean \pm standard error of the mean. (A) $10 \mu \mathrm{M}$ phenanthrolin; (B) $100 \mu \mathrm{M}$ leupeptin; (C) $10 \mu \mathrm{M}$ pepstatin; and (D) $10 \mathrm{mg} / \mathrm{ml}$ aprotinin. "P<0.05 and ${ }^{* *} \mathrm{P}<0.001$ vs. 0 h. DNP, dendroaspis natriuretic peptide; HPLC, high-pressure liquid chromatography. 
increased the degradation of ${ }^{125} \mathrm{I}$-labeled DNP from $1 \mathrm{~h}$ of incubation in tissue extracts from the kidney cortex. Finally, pepstatin, an acid-proteinase inhibitor, significantly increased the degradation of the radioactivity of ${ }^{125}$ I-labeled DNP. Therefore, these results indicate that the degradation of DNP may be mediated by a metalloproteinase.

\section{Discussion}

The aim of the present study was to further analyze the metabolic fate of DNP in rat plasma and to identify a physiological target site for the degradation of DNP in the organs. The results revealed that DNP is stable and may have a more conservative molecular structure compared with any of the other NPs against the endogenous peptidases in plasma. More significantly, the organ that metabolizes DNP may be the kidney, and degradation of DNP may be mediated by a metalloproteinase.

The present study was undertaken to compare NP stability in plasma for the first time, and the results clearly reveal evidence of the different stabilities of the NPs in rat plasma. Time-dependent degradation was identified to occur in the rank order of $\mathrm{DNP} \gg>>\mathrm{ANP} \geq \mathrm{BNP}>>\mathrm{CNP}$ in the incubated rat plasma. DNP was less degraded than any other peptides, while CNP was easily destroyed by theprotein enzyme. A noteworthy aspect of the present study was the observation that ${ }^{125} \mathrm{I}$-labeled DNP was not degraded until undergoing a 4-h incubation in plasma, while ${ }^{125}$ I-labeled CNP, BNP and ANP were significantly degraded in a time-dependent manner. These results are in agreement with earlier measurements from our laboratory (Sung Zoo Kim, Department of Physiology, Chonbuk National University, Jeonju, South Korea) demonstrating a noticeably stronger stability of DNP compared with that of ANP in rabbit plasma (14). EDTA was used to inhibit coagulation when the blood was collected. Several studies have revealed a correlation between EDTA and the stability of NPs $(15,16)$. Tan et al $(15)$ demonstrated that no difference was observed in ANP levels with EDTA and without EDTA in plasma sampling conditions. In addition, degradation of ${ }^{125} \mathrm{I}$-ANP was shown to be antagonized by EDTA (16). In the present study, a stability study of DNP was performed using no coagulator (serum), heparin or EDTA when the blood was collected. However, there were no significant differences in the DNP stabilities regardless of the use of the anticoagulators (heparin and EDTA; data not shown). Therefore, it was hypothesized that EDTA is not the main reason for the varying degradation rates between ANP, BNP, CNP and DNP.

The metabolic fate of ANP in plasma is well known (17), along with the fact that it is degraded by a neutral endopeptidase (NEP), which is a metallopeptidase (18). It has been reported that the rank order of hydrolysis by NEP in NPs is $\mathrm{CNP}>\mathrm{ANP}>\mathrm{BNP}$, indicating that a longer length of the $\mathrm{C}$-terminus of the peptide results in a greater resistance to hydrolysis by NEP (19). In the present study, CNP, which has the shortest amino acid sequence ( 22 amino acids), was the most rapidly degraded, while the NP with the longest amino acid sequence, DNP, was stable in the rat plasma. Therefore, the length of the C-terminus appears to be a significant factor affecting the stability of NPs. Perhaps the long half-life of
DNP in plasma may be due to the strong resistance of DNP to degradation by an endopeptidase. Therefore, these results indicate that DNP may have a different metabolic fate compared with other NPs and that it may be applicable as a therapeutic agent for cardiac diseases, including congestive heart failure or hypertension. Thus, the present findings indicate that DNP is extremely stable in plasma compared with other NPs. Nevertheless, the reason for the strong stability of DNP in plasma is unknown.

Unlike the other NPs, DNP did not easily degrade in the plasma. In addition, the present study sought to determine the physiological target sites for the clearance of DNP in organs. In the present study, ${ }^{125}$ I-labeled DNP was rapidly degraded in tissue extracts from the renal cortex and medulla during incubation at $37^{\circ} \mathrm{C}$ for $1 \mathrm{~h}$, while the tissue extracts from the spleen, lung, heart and liver were relatively stable for the same time. The kidney appears to be the major organ for the degradation of DNP. It is noteworthy that the degradation of ${ }^{125}$ I-labeled DNP in the tissue extracts from the renal cortex occurred in a time-dependent manner. ANP is degraded by the renal brush border membrane of the proximal tubule, which is extraordinarily rich in degradative enzymes (20-22). The renal brush border is not the only site of ANP degradation by NEP, although the kidney has the greatest capacity for peptide degradation $(23,24)$. NEP is also disseminated in the thyroid, lung, brain, parts of the intestine, seminal vesicles, prostate, vascular tissue and plasma $(25,26)$. BNP is hydrolyzed by NEP in renal microvilli $(27,28)$. Therefore, the findings of the present study are somewhat similar to previous studies in that the kidney may be the likely organ responsible for the degradation of DNP.

The effects of proteinase inhibitors were then investigated on ${ }^{125}$ I-DNP stability in tissue extracts from rat kidneys. Phenanthroline, a metalloproteinase inhibitor, reduced the degradation of ${ }^{125}$ I-labeled DNP during incubation for $1 \mathrm{~h}$ in tissue extracts from the renal cortex. Furthermore, following incubation for $4 \mathrm{~h}$, the degradation of ${ }^{125}$ I-labeled DNP remained attenuated by phenanthroline. The present findings are consistent with previous studies $(17,18)$ and indicate the significance of NEP in the inactivation of DNP, similar to ANP, revealing that NEP is involved in the inactivation of BNP and ANP in the plasma. However, these observations are fairly different from an earlier study, which revealed that DNP was resistant to degradation by NEP (29). The discrepancy between the present study and previous observations revealing different degradation abilities of NEP for DNP is difficult to elucidate and further experiments are likely to be required.

In conclusion, DNP was found to have the most stable structure amongst the NPs, which may be responsible for its long half-life. Furthermore, DNP was observed to be destroyed mainly in the kidney by a metalloproteinase.

\section{Acknowledgements}

The authors would like to thank Professor Kyung Woo Cho for the valuable critique and comments. This study was supported by the Basic Science Research Program through the National Research Foundation of Korea, funded by the Ministry of Education, Science and Technology (grant nos. 2011-0014864 and 2012-0009322). 


\section{References}

1. de Bold AJ: Atrial natriuretic factor: a hormone produced by the heart. Science 230: 767-770, 1985.

2. de Bold AJ: Atrial natriuretic factor: an overview. Fed Proc 45 2081-2085, 1986

3. Sudoh T, Kangawa K, Minamino N and Matsuo H: A new natriuretic peptide in porcine brain. Nature 332: 78-81, 1988.

4. Sudoh T, Minamino N, Kangawa K and Matsuo H: C-type natriuretic peptide $(\mathrm{CNP})$ : a new member of natriuretic peptide family identified in porcine brain. Biochem Biophys Res Commun 168: 863-870, 1990

5. Schweitz H, Vigne P, Moinier D, Frelin C and Lazdunski M: A new member of the natriuretic peptide family is present in the venom of the green mamba (Dendroaspis angusticeps). J Biol Chem 267: 13928-13932, 1992.

6. Nakao K, Mukoyama M,Hosoda K, et al: Biosynthesis, secretion, and receptor selectivity of human brain natriuretic peptide. Can J Physiol Pharmacol 69: 1500-1506, 1991

7. Stoupakis G and Klapholz M: Natriuretic peptides: biochemistry, physiology, and therapeutic role in heart failure. Heart Dis 5: 215-223, 2003

8. Scotland RS, Ahluwalia A and Hobbs AJ: C-type natriuretic peptide in vascular physiology and disease. Pharmacol Ther 105: $85-93,2005$

9. Januszewicz A: The natriuretic peptides in hypertension. Curr Opin Cardiol 10: 495-500, 1995.

10. Kim SM, Kim YA, Kim SY, Kim SH, Cho KW and Kim SZ: Presence of dendroaspis natriuretic peptide and its binding to NPR-A receptor in rabbit kidney. Regul Pept 167: 42-49, 2011.

11. Cho KW, Kim SH, Kim CH and Seul KH: Mechanical basis of ANP secretion in beating atria: atrial stroke volume and ECF translocation. Am J Physiol 268: R1129-R1136, 1995.

12. Morris BJ: Specific radioactivity of radioimmunoassay tracer determined by self-displacement: a re-evaluation. Clin Chim Acta 73: 213-216, 1976.

13. Joseph LJ, Desai KB, Mehta MN and Mathiyarasu R Measurement of specific activity of radiolabelled antigens by a simple radioimmunoassay technique. Int J Rad Appl Instrum B 15: 589-590, 1988.

14. Kim SM, Kim SY, Kim SH, Cho KW and Kim SZ: Renal actions of dendroaspis natriuretic peptide in rabbits. Peptides 33: 59-66, 2012

15. Tan AC, Rosmalen FM, Theelen BG, Kloppenborg PW, Benraad HB and Benraad TJ: Atrial natriuretic peptide - the influence of various physiological and sampling conditions. Ann Clin Biochem 24: 500-507, 1987.

16. Rugg EL, Aiton JF and Cramb G: Degradation of [125I]-atrial natriuretic peptide by a soluble metallopeptidase isolated from rat ventricular myocytes. Biochem Biophys Res Commun 152 294-300, 1988
17. Olins GM, Spear KL, Siegel NR, Reinhard EJ and Zurcher-Neely HA: Atrial peptide inactivation by rabbit-kidney brush-border membranes. Eur J Biochem 170: 431-434, 1987.

18. Lisy O, Jougasaki M, Schirger JA, Chen HH, Barclay PT and Burnett JC Jr: Neutral endopeptidase inhibition potentiates the natriuretic actions of adrenomedullin. Am J Physiol 275: F410-F414, 1998.

19. Dussaule JC: Natriuretic factors of cardiac origin: renal effects. Rev Prat 43 (20 Suppl): 13-17, 1993 (In French).

20. Stephenson SL and Kenny AJ: The hydrolysis of alpha-human atrial natriuretic peptide by pig kidney microvillar membranes is initiated by endopeptidase-24.11. Biochem J 243: 183-187, 1987.

21. Stephenson SL and Kenny AJ: The metabolism of neuropeptides. Hydrolysis of peptides by the phosphoramidon-insensitive rat kidney enzyme 'endopeptidase-2' and by rat microvillar membranes. Biochem J 255: 45-51, 1988.

22. Johnson GR, Arik L and Foster CJ: Metabolism of 125I-atrial natriuretic factor by vascular smooth muscle cells. Evidence for a peptidase that specifically removes the COOH-terminal tripeptide. J Biol Chem 264: 11637-11642, 1989.

23. Erdös EG and Skidgel RA: Neutral endopeptidase 24.11 (enkephalinase) and related regulators of peptide hormones. FASEB J 3: 145-151, 1989.

24. Erdös EG, Wagner B, Harbury CB, Painter RG, Skidgel RA and Fa XG: Down-regulation and inactivation of neutral endopeptidase 24.11 (enkephalinase) in human neutrophils. J Biol Chem 264: 14519-14523, 1989.

25. Yandle TG, Brennan SO, Espiner EA, Nicholls MG and Richards AM: Endopeptidase-24.11 in human plasma degrades atrial natriuretic factor (ANF) to $\mathrm{ANF}(99-105 / 106-126)$. Peptides 10: 891-894, 1989.

26. Tamburini PP, Koehn JA, Gilligan JP, et al: Rat vascular tissue contains a neutral endopeptidase capable of degrading atrial natriuretic peptide. J Pharmacol Exp Ther 251: 956-961, 1989.

27. Bourne A and Kenny AJ: The hydrolysis of brain and atrial natriuretic peptides by porcine choroid plexus is attributable to endopeptidase-24.11. Biochem J 271: 381-385, 1990.

28. Vanneste Y, Pauwels S, Lambotte L and Deschodt-Lanckman M: In vivo metabolism of brain natriuretic peptide in the rat involves endopeptidase 24.11 and angiotensin converting enzyme. Biochem Biophys Res Commun 173: 265-271, 1990.

29. Chen HH, Lainchbury JG and Burnett JC Jr: Natriuretic peptide receptors and neutral endopeptidase in mediating the renal actions of a new therapeutic synthetic natriuretic peptide dendroaspis natriuretic peptide. J Am Coll Cardiol 40: 1186-1191, 2002. 